\title{
Physicochemical and Sensory Properties of Gummy Candies Enriched with Pineapple and Papaya Peel Powders
}

\author{
Karla Fabiola Romo-Zamarrón ${ }^{1}$, Laura Eugenia Pérez-Cabrera1, Alberto Tecante ${ }^{2 *}$ \\ ${ }^{1}$ Departamento de Tecnología de Alimentos, Universidad Autónoma de Aguascalientes, Aguascalientes, México \\ ${ }^{2}$ Departamento de Alimentos y Biotecnología, Facultad de Química, Universidad Nacional Autónoma de México, \\ Mexico City, México \\ Email: *tecante@unam.mx
}

How to cite this paper: Romo-Zamarrón, K.F., Pérez-Cabrera, L.E. and Tecante, A. (2019) Physicochemical and Sensory Properties of Gummy Candies Enriched with Pineapple and Papaya Peel Powders. Food and Nutrition Sciences, 10, 1300-1312. https://doi.org/10.4236/fns.2019.1011094

Received: October 15, 2019

Accepted: November 11, 2019

Published: November 14, 2019

Copyright $\odot 2019$ by author(s) and Scientific Research Publishing Inc. This work is licensed under the Creative Commons Attribution International License (CC BY 4.0).

http://creativecommons.org/licenses/by/4.0/

\begin{abstract}
Currently, the production of minimally processed foods generates many by-products that are not optimally exploited. Pineapple and papaya peels dehydrated by circulating hot air and freeze drying, with different particle sizes, were used as powder ingredients to enrich gummy candies. Modifications in soluble solids $\left({ }^{\circ} \mathrm{Bx}\right), \mathrm{pH}$, water activity $\left(a_{w}\right)$, color, instrumental texture, and sensory perception of the products were assessed regarding powder-free controls. The inclusion of $5 \mathrm{~g} / 100 \mathrm{~g}$ of each fruit peel powder resulted in candies with stable acidity, ${ }^{\circ} \mathrm{Bx}, a_{w}$ and $\mathrm{pH}$. Freeze-dried peels with smaller particle size produced better physicochemical, sensory, instrumental texture, and color characteristics because the powders were easily and homogeneously distributed, reinforcing thus the structure of the gel, and producing better coloring.
\end{abstract}

\section{Keywords}

Candy Gel, Papaya, Pineapple, Powders

\section{Introduction}

Presently, the efficient and concerned use of by-products from the food industry minimizes the environmental impact [1] and is highly profitable due to the nutritional and functional properties of these by-products: which go from physiological effects to technological properties [2] [3]. Micro and small-scale food-processing units generate a non-negligible volume of this type of waste, but they do not treat the produced residues. However, these by-products are rich in moisture and microbial loads, and when not treated properly result in environmental 
contamination [1].

Fresh pineapple and papaya are the fruits most sold throughout the year in many countries because of their various nutritional and diuretic qualities [4] [5]. However, about $25 \%$ to $50 \%$ of the mass of the pineapple [6] [7], and approximately $20 \%$ to $25 \%$ of the mass of the papaya [8], are considered as by-products not usable by humans [9]. The peels of these and other fruits are a source of dietary fiber and antioxidants [10] [11]. An alternative of using these by-products is through the production of food powders, since in this way, it is easier to incorporate and dose them in the development of new foods [12]. However, the particle size and the dehydration process used for their production can interfere mainly in their $\mathrm{pH}, a_{w}$ color and texture, limiting their use in certain food products [13].

Pineapple by-products have been applied and assessed as fat replacers in hamburger meat [2], fiber-content improvers in extruded products [14], and probiotic yogurt [15]. However, there are no reports on their use in the elaboration of candies or gummy candies. This situation is relevant because Mexico is the sixth most important producer and consumer of confectionery products in the world and the second in Latin America [16]. However, the high consumption of such products is recognized as lacking in nutritional value [17], for the high content of sweeteners whose prolonged consumption increases the risk of suffering from diabetes and obesity at an early age [18]. This type of products also contains artificial dyes. According to various studies consumption of such components above permissible limits can cause respiratory problems, allergy, thyroid tumors, chromosomal damage, hyperactivity, and abdominal pain, among many others [18] [19].

For all these reasons, this work could contribute to reevaluate minimally processed pineapple and papaya peels generated by the small-scale horticultural food industry. Therefore, the objective was to elaborate gummy candies replacing sweeteners, flavoring and colorings with pineapple and papaya peels as powders with a high content of antioxidant dietary fiber and evaluate their contribution to the physicochemical and sensory properties of the products. The results are expected to encourage the utilization of such wastes based on scientific information about their properties and attributes.

\section{Materials and Methods}

\subsection{Raw Materials}

Pineapple and papaya peels by-products generated from minimal fresh fruit processing were collected from two local small-scale food units (Las Exquisitas Food \& Snacks, and Jugos y Chocos Tony). Bulk refined sugar, corn starch glucose (45 Globe/Gloria 2534, Ingredion México S.A. de C.V.), unflavored powder gelatin Bloom 290 (Coloidales Duche S.A. de C.V), citric acid (MABI), Capol 3073A (a release agent for gums and jellies with highly stable vegetable oils and natural waxes; Capol $\mathrm{GmbH}$ ), chamoy and pineapple flavoring (Deiman S.A. de 
C.V.) and bulk cornstarch, were obtained from the local market.

\subsection{Pineapple and Papaya Peel Powders Preparation and Characterization}

The peels free of mold and visible degradation were selected, washed and disinfected by immersion for $10 \mathrm{~min}$ in a solution $(2 \mathrm{~mL} / 10 \mathrm{~L}$ water) of Nicon-PQ (active component citric acid: Procesadores de Aditivos S.A. de C.V., Investa de México S.A. de C.V., Mexico), and subsequently submerged in water at $90^{\circ} \mathrm{C}$ to inactivate enzymes. The excess of solution was removed in a vegetables centrifuge (Ilko, México), and the peels separated into two batches for each by-product. The first batch was dried with circulating hot air (Excalibur Products, 3500, USA) at $57^{\circ} \mathrm{C}$ for 16 to $24 \mathrm{~h}$ for pineapple peels, and $8 \mathrm{~h}$ for papaya peels. The second batch, previously frozen to $-78^{\circ} \mathrm{C}$ (SO-LOW, U40-13, USA), was freeze-dried in a laboratory unit (Labconco, FreeZone ${ }^{\circledR}$ Legacy, 7752020, USA) at $0.0099^{\circ} \mathrm{C}$ and $610.5 \mathrm{~Pa}$ vacuum. The dehydrated peels were ground (Oster, 6859, MX) and sieved (Quimilab, Sieves, Flicc, S.A. de C.V.) for $30 \mathrm{~min}$. The pineapple peel powder was divided into three particle size fractions: greater than $300 \mu \mathrm{m}, 250 \mu \mathrm{m}$, and lower that $180 \mu \mathrm{m}$. That of papaya was divided into two fractions: greater than $300 \mu \mathrm{m}$, and 250 to less than $180 \mu \mathrm{m}$ (because the yield of papaya peel powders with particle size of 250 was low). Six different pineapple peel powders, labeled as Pi-HA-1, Pi-HA-2, Pi-HA-3, Pi-LYO-1, Pi-LYO-2 and Pi-LYO-3, and four of papaya peels powders, identified as Pa-HA-1, Pa-HA-2, Pi-LYO-1 and Pi-LYO-2, were obtained, where HA stands for air dried and LYO for freeze-dried.

The properties of the powders were determined: Moisture [20]; Total dietary fiber [20]; Water activity; DPPH [21]; ABTS [22]; and Polyphenols [23] are shown in Table 1.

\subsection{Formulation and Production of Gummy Candies}

Control gummy candies, i.e. without fruit peel powders, were made according to an existing formulation [24]. This formulation was adapted to prepare the modified gels as follows; $50 \mathrm{mg} / \mathrm{g}$ sucrose was replaced by pineapple or papaya powder. Artificial colorant was not added, and flavoring was not added to

Table 1. Main properties of pineapple and papaya powders.

\begin{tabular}{ccc}
\hline Parameter & Pineapple & Papaya \\
\hline Moisture (\%) & $4.19 \pm 0.28-5.44 \pm 0.05$ & $6.07 \pm 0.06-8.07 \pm 0.05$ \\
Dietary fiber (\%) & $38.99 \pm 0.04-45.67 \pm 0.47$ & $17.35 \pm 0.50-21.69 \pm 0.40$ \\
Water activity & $0.319 \pm 0.001-0.399 \pm 0.001$ & $0.300 \pm 0.007-0.378 \pm 0.002$ \\
DPPH & $364.00 \pm 0.03-367.80 \pm 0.07$ & $684.6 \pm 0.06-689.3 \pm 0.08$ \\
ABTS & $34.20 \pm 0.04-36.20 \pm 0.03$ & $46.20 \pm 0.02-47.00 \pm 0.04$ \\
Polyphenols & $34.10 \pm 0.03-56.50 \pm 0.04$ & $16.70 \pm 0.32-40.70 \pm 0.40$
\end{tabular}

${ }^{\star}$ mg eq. Trolox ${ }^{\circledR} / 100$ g d.b.; ${ }^{* *}$ mg eq. gallic acid/100 g d.b.; d.b. = dry basis. 
pineapple formulation. However, $1 \mathrm{mg} / \mathrm{g}$ of chamoy flavor was added to papaya formulation to counteract the strong taste of papaya. Citric acid was decreased by $2.8 \mathrm{mg} / \mathrm{g}$ because of the content of organic acids of the powders (Table 2).

To produce the gummy candies, gelatin was hydrated with $0.453 \mathrm{~g} / \mathrm{g}$ of the total water of the formulation and left to stand for $30 \mathrm{~min}$. Sucrose was dissolved with the remaining $0.546 \mathrm{~g} / \mathrm{g}$ of the water at a temperature of $70^{\circ} \mathrm{C}$, then glucose was added the blend cooked until it reached $105^{\circ} \mathrm{C}$. The hydrated gelatin was added immediately to the control formulations and mixed to homogenize the ingredients. Then the citric acid previously dissolved in water, flavor (pineapple or chamoy) and yellow color were added for the pineapple control, and orange for the papaya one. For the modified gummy candies, after concentrating the syrup, the powders of pineapple or papaya peel were added and mixed. The hydrated gelatin was added and mixed to homogenize the ingredients, then the citric acid previously dissolved in water was added, and chamoy flavor only for papaya gels. The resulting gels were molded in starch chests to hemisphere molds, $1.5 \mathrm{~cm}$ in diameter, and gelled at $23^{\circ} \mathrm{C}$ for $24 \mathrm{~h}$. The gummy candies were demolded, brushed, waxed with Capol and stored in polypropylene bottles at $20^{\circ} \mathrm{C}$. The products were labeled as Control-Pi, G-Pi-HA-1, G-Pi-HA-2, G-Pi-HA-3, G-Pi-LYO-1, G-Pi, LYO-2, G-Pi-LYO-3 for pineapple, and Control-Pa, G-Pa-HA-1, Pa-HA-2, Pa-LYO-1, Pa-LYO-2 for papaya/chamoy.

\subsection{Physicochemical Properties}

The content of soluble solids $\left({ }^{\circ} \mathrm{Bx}\right)$ at $20^{\circ} \mathrm{C}$ determined in a refractometer (Atago, $\mathrm{H}-93$, USA), and $\mathrm{pH}$ at $25^{\circ} \mathrm{C}$ measured with a potentiometer (Hanna Instruments, HI99163, USA) previously calibrated with buffer solutions $\mathrm{pH}=7$ and 4 were measured in triplicate. Water activity $\left(a_{w}\right)$ was determined at $25^{\circ} \mathrm{C}$ in a meter (Decagon Devices, Inc., AquaLab Series 3TE, USA) previously calibrated with aqueous standards of $a_{w}=0.250(13.4 \mathrm{~mol} / \mathrm{kg} \mathrm{LiCl}), a_{w}=0.5(8.57 \mathrm{~mol} / \mathrm{kg} \mathrm{LiCl})$, and $a_{w}=0.984(0.5 \mathrm{~mol} / \mathrm{kg} \mathrm{KCl})$. Instrumental color was determined in a colorimeter (Konica Minolta Sensing Americas, Inc, CR-400, Japan) and CIE- $L^{\star} C^{\star} h^{\star}$

Table 2. Formulations of gummy candies in percentage.

\begin{tabular}{cccc}
\hline Ingredient & Control & Pineapple & Papaya \\
\hline Gelatin $\left(290^{\circ}\right.$ Bloom $)$ & 5.30 & 5.30 & 5.3 \\
Water & 23.38 & 23.38 & 23.38 \\
Saccharose & 33.20 & 28.82 & 28.82 \\
Glucose & 36.50 & 36.50 & 36.50 \\
Citric Acid & 1.28 & 1.00 & 0 \\
Colorant & 0.04 & 0 & 0.1 \\
Flavouring & 0.30 & 0 & 0 \\
Powder by-products of pineapple & 0 & 5 & 5 \\
Powder by-products of papaya & 0 & 0 & 0 \\
\hline
\end{tabular}


coordinates (luminosity, $\mathrm{L}^{\star}$, chroma, $\mathrm{C}^{\star}$, and hue, $\mathrm{h}^{\star}$ ) were obtained.

The texture profile analysis of one-day old hemispheric specimens $1.5 \mathrm{~cm}$ in diameter, and $1.5 \mathrm{~cm}$ in height was carried out at $20^{\circ} \mathrm{C}$ in a texturometer (Stable Micro System, TA-XTplus, UK). Two different tests were run. The first one was done using an adaptation of the Gummy Confectionery Test available in the texturometer software. A cylindrical probe (compression platen $\mathrm{P} / 75,75 \mathrm{~mm}$ in diameter), a heavy-duty platform adjusted with a flat plate (HDP/90) and a trigger force of $50 \mathrm{mN}$ were used. Before running the test, the probe was calibrated to recognize the analyzer's test surface (100\% voltage), and the distance (20 $\mathrm{mm})$ back from the probe after compression was selected. Each gummy candy was compressed to $20 \%$ of his original height, at a speed of $1.0 \mathrm{~mm} / \mathrm{s}$. The cell was kept at this distance for $60 \mathrm{~s}$ and then removed to its initial position at a speed of $10.0 \mathrm{~mm} / \mathrm{s}$. The MACRO of the resulting force-distance curve was run, and the following texture properties recorded: firmness which corresponds to the total strength $(\mathrm{N})$ of the specimen, and elasticity (\%) which corresponds to the height that the sample recovers after being compressed.

The second test was an adaptation to the testing standard of the Gelatin Manufacturers Institute of America [25]. A cylindrical Derlin probe (P/0.5R, $1.27 \mathrm{~cm}$ in diameter), a heavy-duty platform adjusted with a flat plate (HDP/90) and a trigger force of $50 \mathrm{mN}$ were used. The specimen was placed on the base aligned centrally under the probe and penetrated at a speed of $1.0 \mathrm{~mm} / \mathrm{s}$, and a depth of $4 \mathrm{~mm}$ (maximum force). The MACRO of the resulting force-distance curve was run and expressed as "gel strength/bloom value" (g) of the gummy candy gel. Water activity, color and texture were determined in ten candies per formulation.

\subsection{Sensory Analysis}

Two tests were carried out with an untrained panel of fifty customary consumers of this type of product in the range of 18 - 25 years old, with the same number of females and males. The selection was based on a survey of habits to rule out people allergic to the product, as well as frequent consumers of alcohol and cigarettes. The first analysis was done to select the preferred particle size by means of an acceptance test of preference at a level of significance of 5\%. Once the preferred particle size was selected, a second sensory analysis was carried out with the preferred samples. The test consisted of a five-point hedonic scale to express how close color intensity, firmness, pineapple or papaya/chamoy flavor, elasticity, sweetness and acidity were to those preferred by the panelists, i.e. $1=$ too weak, 2 = a little weak, 3 = just as I like it, $4=$ a bit strong, $5=$ too strong [26]. The samples were presented as a $1.5 \mathrm{~cm}$ diameter hemisphere at room temperature $\left(20^{\circ} \mathrm{C}-22^{\circ} \mathrm{C}\right)$ in random order and were labeled with randomly generated three-digit codes.

\subsection{Statistical Analysis}

Data of the physicochemical analyses and results of satisfaction tests using hedonic scales of gummy candies were expressed as mean \pm standard deviation ( $\mathrm{n}$ 
$=3$ ) and subjected to normality and homoscedasticity analysis. One-way analysis of variance (ANOVA) was used applying Tukey's analysis for means with significant differences $(\mathrm{p}<0.05)$ in physicochemical analyses and Fisher's LSD for satisfaction tests. Data were analyzed using the statistical package InfoStat for Windows. Results of preference test were expressed as frequency of the number of scores given by the panelists. Tables of significance were used at a confidence level of $5 \%$.

\section{Results and Discussion}

\subsection{Physicochemical Properties}

There were no differences $(\mathrm{p}<0.05)$ in the content of soluble solids $\left({ }^{\circ} \mathrm{Bx}\right)$ between the samples prepared with pineapple or papaya peel powders and their respective controls (Table 3). This result indicates an improvement in the quality of the product and serves to fix the final concentration of soluble solids necessary to maintain the physicochemical stability of the gelled candies [27].

The $\mathrm{pH}$ showed differences $(\mathrm{p}<0.05)$ between the different formulations and their controls; pineapple gummy candies exhibited the lowest $\mathrm{pH}$. This result is explained by the acidity of the pineapple powder. The $\mathrm{pH}$ of the products with papaya peel powder was significantly $(\mathrm{p}<0.05)$ higher than that of their control because papaya is less acid than pineapple. However, the $\mathrm{pH}$ range of the products was 3.0 to 4.5 , which is recommended for gummies made with $290^{\circ}$ Bloom gelatin [24]. The $\mathrm{pH}$ of the product is critical; a very low $\mathrm{pH}$ is not desirable because the product will not be stable, or a gel might not be formed. If a hydrocolloid

Table 3. ${ }^{\circ} \mathrm{Bx}, \mathrm{pH}$, and $a_{w}$ of enriched gummy candies and their controls ${ }^{\star *}$.

\begin{tabular}{|c|c|c|c|}
\hline Sample* & ${ }^{\circ} \mathrm{Bx}$ & $\mathrm{pH}$ & $a_{W}$ \\
\hline Control & $72 \pm 0.000$ & $3.60 \pm 0.001^{\mathrm{a}}$ & $0.544 \pm 0.002^{\mathrm{a}}$ \\
\hline G-Pi-HA-1 & $70 \pm 0.000$ & $3.51 \pm 0.035^{\mathrm{b}}$ & $0.600 \pm 0.023^{\mathrm{ab}}$ \\
\hline G-Pi-HA-2 & $70 \pm 0.000$ & $3.57 \pm 0.173^{b}$ & $0.570 \pm 0.010^{\mathrm{b}}$ \\
\hline G-Pi-HA-3 & $70 \pm 0.000$ & $3.57 \pm 0.017^{\mathrm{b}}$ & $0.600 \pm 0.012^{\mathrm{b}}$ \\
\hline G-Pi-LYO-1 & $70 \pm 0.000$ & $3.52 \pm 0.037^{\mathrm{b}}$ & $0.550 \pm 0.009^{\mathrm{a}}$ \\
\hline G-Pi-LYO-2 & $70 \pm 0.000$ & $3.50 \pm 0.000^{\mathrm{b}}$ & $0.540 \pm 0.006^{\mathrm{a}}$ \\
\hline G-Pi-LYO-3 & $70 \pm 0.000$ & $3.51 \pm 0.072^{\mathrm{b}}$ & $0.560 \pm 0.015^{\mathrm{a}}$ \\
\hline Anova & 1.0000 & 0.0002 & 0.0003 \\
\hline Control & $72 \pm 0.000$ & $3.60 \pm 0.000^{\mathrm{a}}$ & $0.544 \pm 0.002^{\mathrm{a}}$ \\
\hline G-Pa-HA-1 & $70 \pm 0.000$ & $3.85 \pm 0.081^{\mathrm{b}}$ & $0.647 \pm 0.032^{b}$ \\
\hline G-Pa-HA-2 & $70 \pm 0.000$ & $3.81 \pm 0.026^{\mathrm{b}}$ & $0.631 \pm 0.054^{\mathrm{b}}$ \\
\hline G-Pa-LYO-1 & $70 \pm 0.000$ & $3.80 \pm 0.010^{\mathrm{b}}$ & $0.635 \pm 0.054^{\mathrm{b}}$ \\
\hline G-Pa-LYO-2 & $70 \pm 0.000$ & $3.92 \pm 0.04^{\mathrm{b}}$ & $0.584 \pm 0.013^{\mathrm{ab}}$ \\
\hline Anova & 1.0000 & 0.0001 & 0.0111 \\
\hline
\end{tabular}

${ }^{*}$ Control = powder-free, $\mathrm{G}=$ gummy, $\mathrm{Pi}=$ pineapple; $\mathrm{Pa}=$ papaya; $\mathrm{HA}=$ dehydrated with circulating hot air; LYO = freeze-dried. Pineapple: $1=\geq 300 \mathrm{~mm}, 2=250 \mathrm{~mm}, 3 \leq 180 \mathrm{~mm}$. Papaya: $1 \geq 300 \mathrm{~mm}, 2=250$ $\mathrm{mm}$ to $<180 \mathrm{~mm}$. ${ }^{*}$ Different letters in each column indicate significant difference $(\mathrm{p}<0.05)$. 
is maintained at its isoelectric point, $\mathrm{pH}$ for which the net charge is zero, then gelation is likely to occur [27].

Water activities of the enriched gummy candies showed significant differences $(\mathrm{p}<0.05)$ (Table 3). The $a_{w}$ of the controls was less, however, all the gummy candies comply with the range of water activity recommended for this type of products ( 0.54 to 0.66$)$ since a higher value would favor microbiological degradation of the product due to its sugar content [24]. Therefore, it was established that enrichment of the gelled candies with pineapple and papaya peel powders does not interfere with the physicochemical and microbiological stability of the products, since they had low $\mathrm{pH}$, low moisture, high content of soluble solids and reduced $a_{w}$ All these factors are important to obtain good quality products [24] [27].

Color is an important indicator of quality and acceptability of foods [28]. Table 4 shows the results of color determination of pineapple and papaya gummy candies. Luminosity, hue and chroma of the controls and the modified gummy candies were significantly different $(\mathrm{p}<0.05)$.

The gummy candies modified with pineapple powders were less luminous with a more intense saturation and a yellow-brown color. The control of papaya/chamoy had greater luminosity, but chroma and hue indicate a more saturated orange color regarding the modified gummy candies. However, pineapple G-Pi-LYO-3 and papaya G-Pa-LYO-2 samples are the closest to the controls. The insoluble dietary fiber of the powders interferes with color in both gummy candies [2] [29]. The fiber does not dissolve and therefore the particle size plays an important role in color. The smaller the particle, the more homogeneous is the distribution of the powders in the product and these results in a better color.

Table 4. Color instrumental of enriched gummy candies and their controls.

\begin{tabular}{cccc}
\hline Sample & $\mathrm{L}^{*}$ & $\mathrm{C}^{*}$ & $\mathrm{~h}^{\circ}$ \\
\hline Control & $60.20 \pm 0.01^{\mathrm{d}}$ & $8.14 \pm 0.67^{\mathrm{a}}$ & $90.41 \pm 0.35^{\mathrm{c}}$ \\
G-Pi-HA-1 & $57.43 \pm 1.59^{\mathrm{b}}$ & $13.70 \pm 0.64^{\mathrm{b}}$ & $75.47 \pm 1.10^{\mathrm{ab}}$ \\
G-Pi-HA-2 & $57.97 \pm 1.16^{\mathrm{b}}$ & $15.11 \pm 0.62^{\mathrm{c}}$ & $76.16 \pm 0.43^{\mathrm{ab}}$ \\
G-Pi-HA-3 & $54.27 \pm 0.64^{\mathrm{a}}$ & $13.34 \pm 0.72^{\mathrm{b}}$ & $75.99 \pm 0.51^{\mathrm{ab}}$ \\
G-Pi-LYO-1 & $57.99 \pm 1.11^{\mathrm{b}}$ & $23.45 \pm 0.17^{\mathrm{cd}}$ & $70.85 \pm 0.52^{\mathrm{a}}$ \\
G-Pi-LYO-2 & $58.97 \pm 0.65^{\mathrm{c}}$ & $23.19 \pm 0.52^{\mathrm{d}}$ & $80.60 \pm 0.72^{\mathrm{abc}}$ \\
G-Pi-LYO-3 & $59.78 \pm 0.70^{\mathrm{cd}}$ & $15.39 \pm 0.69^{\mathrm{c}}$ & $77.55 \pm 1.07^{\mathrm{bc}}$ \\
Anova & 0.0001 & 0.0001 & 0.0001 \\
Control & $58.81 \pm 1.38^{\mathrm{b}}$ & $16.05 \pm 0.76^{\mathrm{a}}$ & $76.44 \pm 0.69^{\mathrm{d}}$ \\
G-Pa-HA-1 & $56.16 \pm 0.82^{\mathrm{a}}$ & $21.23 \pm 0.59^{\mathrm{b}}$ & $70.01 \pm 0.66^{\mathrm{a}}$ \\
G-Pa-HA-2 & $57.88 \pm 1.15^{\mathrm{b}}$ & $23.20 \pm 1.39^{\mathrm{c}}$ & $70.92 \pm 0.58^{\mathrm{b}}$ \\
G-Pa-LYO-1 & $56.42 \pm 1.87^{\mathrm{a}}$ & $20.45 \pm 1.11^{\mathrm{b}}$ & $70.98 \pm 0.54^{\mathrm{b}}$ \\
G-Pa-LYO-2 & $58.93 \pm 1.54^{\mathrm{b}}$ & $24.64 \pm 1.61^{\mathrm{d}}$ & $71.83 \pm 0.40^{\mathrm{c}}$ \\
Anova & 0.0001 & 0.0001 & 0.0001 \\
\hline
\end{tabular}


Table 5 also shows the results of the instrumental texture measurements of the gelled candies. The modified candies were firmer, more elastic, but with lower strength, compared to the control samples. These results are consistent with those reported by Cappa et al. (2015) [28], who developed gel-like fruit candies (GLFC) based on apple and cranberry modified with grape skin powder of different particle sizes, using pectin as a gelling agent. These authors demonstrated that the powders and their particle size modify the instrumental texture of the GLFC. The particle size of the powders plays an important role on the mechanical properties, i.e. hardness and energy required for penetration, since a larger particle size results in a smaller force to penetrate the sample.

\subsection{Sensory Analysis}

\subsubsection{Preference Tests: Selection of the Particle Size of the Powders}

Figure 1 shows the results of the test to select the preferred particle size for the pineapple and papaya powders added to the gummy candies. To establish the preference with a level of significance of $5 \%$ in pineapple gels, it is necessary that 24 out of 50 panelists prefer any fraction. Thus, the panelists preferred the particle size $<180 \mu \mathrm{m}$ as 34 out of 50 of them selected this fraction. In the case of papaya gels, it is required that 33 out of 50 panelists select a given particle size fraction to have a level of significance of $5 \%$. Using this criterion, the panelists preferred the particle size fraction from 250 to $<180 \mu \mathrm{m}$ since 35 out of 50 of them selected that fraction.

\subsubsection{Affective Tests of Degree of Satisfaction}

Figure 2 shows the results of the affective test for the degree of satisfaction of the

Table 5. Instrumental texture of enriched gummy candies and their controls.

\begin{tabular}{cccc}
\hline Sample & Firmness $(\mathrm{N})$ & Elasticity $(\%)$ & Gel strength $(\mathrm{g})$ \\
\hline Control & $8.64 \pm 0.45^{\mathrm{a}}$ & $35.42 \pm 1.64^{\mathrm{a}}$ & $510.4 \pm 39.1^{\mathrm{a}}$ \\
G-Pi-HA-1 & $9.84 \pm 0.07^{\mathrm{b}}$ & $56.07 \pm 2.95^{\mathrm{c}}$ & $664.1 \pm 37.4^{\mathrm{b}}$ \\
G-Pi-HA-2 & $9.88 \pm 0.09^{\mathrm{bc}}$ & $55.77 \pm 2.66^{\mathrm{c}}$ & $679.6 \pm 50.1^{\mathrm{b}}$ \\
G-Pi-HA-3 & $9.98 \pm 0.09^{\mathrm{bcd}}$ & $52.40 \pm 2.38^{\mathrm{b}}$ & $687.8 \pm 56.6^{\mathrm{b}}$ \\
G-Pi-LYO-1 & $9.95 \pm 0.17^{\mathrm{bcd}}$ & $52.31 \pm 1.51^{\mathrm{b}}$ & $682.4 \pm 32.0^{\mathrm{b}}$ \\
G-Pi-LYO-2 & $10.14 \pm 0.17^{\mathrm{cd}}$ & $51.86 \pm 2.12^{\mathrm{b}}$ & $702.7 \pm 18.9^{\mathrm{b}}$ \\
G-Pi-LYO-3 & $10.23 \pm 0.21^{\mathrm{d}}$ & $50.56 \pm 0.92^{\mathrm{b}}$ & $713.1 \pm 10.3^{\mathrm{b}}$ \\
Anova & 0.0001 & 0.0001 & 0.0001 \\
Control & $8.54 \pm 0.47^{\mathrm{a}}$ & $34.92 \pm 2.46^{\mathrm{a}}$ & $490.7 \pm 54.9^{\mathrm{b}}$ \\
G-Pa-HA-1 & $9.55 \pm 0.08^{\mathrm{b}}$ & $52.51 \pm 1.49^{\mathrm{b}}$ & $529.5 \pm 46.1^{\mathrm{a}}$ \\
G-Pa-HA-2 & $9.57 \pm 0.03^{\mathrm{b}}$ & $52.40 \pm 2.38^{\mathrm{b}}$ & $534.9 \pm 41.9^{\mathrm{a}}$ \\
G-Pa-LYO-1 & $9.98 \pm 0.02^{\mathrm{c}}$ & $52.56 \pm 2.12^{\mathrm{b}}$ & $658.2 \pm 25.7^{\mathrm{c}}$ \\
G-Pa-LYO-2 & $10.09 \pm 0.21^{\mathrm{c}}$ & $52.35 \pm 0.92^{\mathrm{b}}$ & $673.3 \pm 278^{\mathrm{c}}$ \\
Anova & 0.0001 & 0.0001 & 0.0001 \\
\hline
\end{tabular}




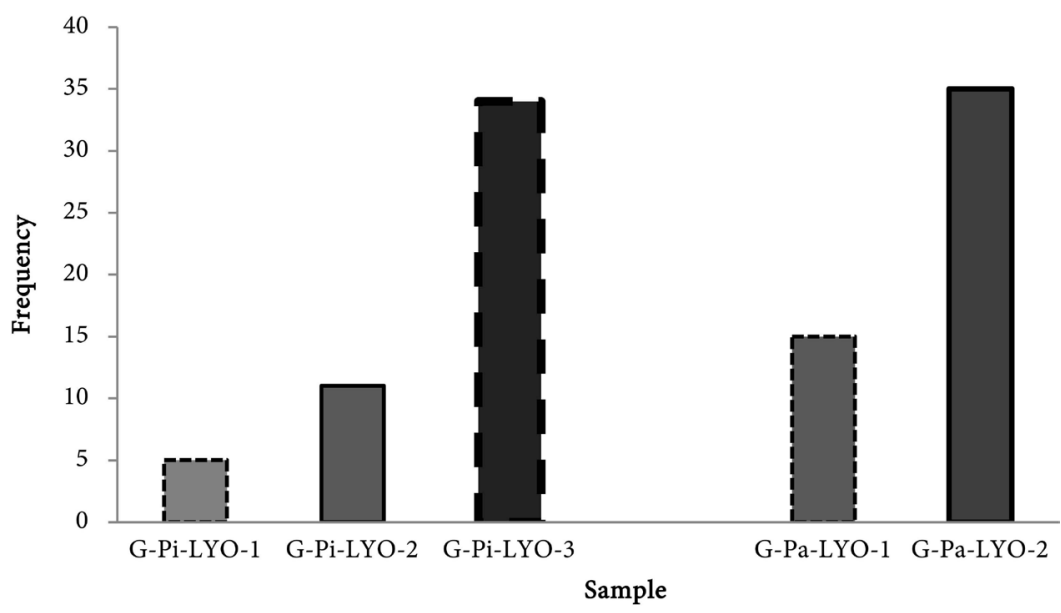

Figure 1. Preference test to select the particle size of the pineapple and papaya peel powders added to the gummy candies, showing the samples preferred by the panelists. See footnotes of Table 3 .

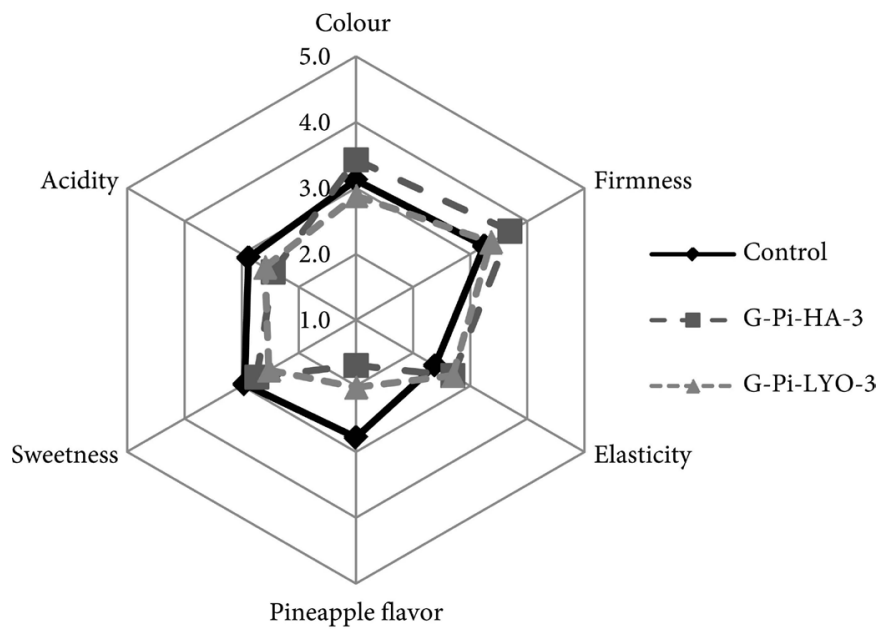

Figure 2. Sensory analysis of pineapple candies using a five-point hedonic scale. Control: powder-free, HA: dehydrated with circulating hot air; LYO: freeze-dried; 3: particle size < $180 \mu \mathrm{m}$.

pineapple candies. Significant differences $(\mathrm{p}<0.05)$ between the control and candies enriched with both powders were observed for sweetness, acidity and pineapple flavor, since the panelists expressed that the attributes of control candies are just as they like them, while the enriched candies were a little less acidic and sweet than they like. Differences in color were also significant $(\mathrm{p}<0.05)$; the panelists pointed out that the color of G-Pi-LYO-3 and G-Pi-HA-3 is slightly weaker and stronger, respectively, than they like, while the color of the control sample was just as they like it. Regarding elasticity and firmness, the panelists liked the elasticity of G-Pi-LYO-3 and G-Pi-HA-3, while the control sample was little less elastic than they like it. Also, all the samples are firmer than they like, however, the enriched candies showed greater firmness.

Figure 3 shows the results of the affective test for the degree of satisfaction of the papaya gummy candies. Significant differences $(p<0.05)$ were observed between 


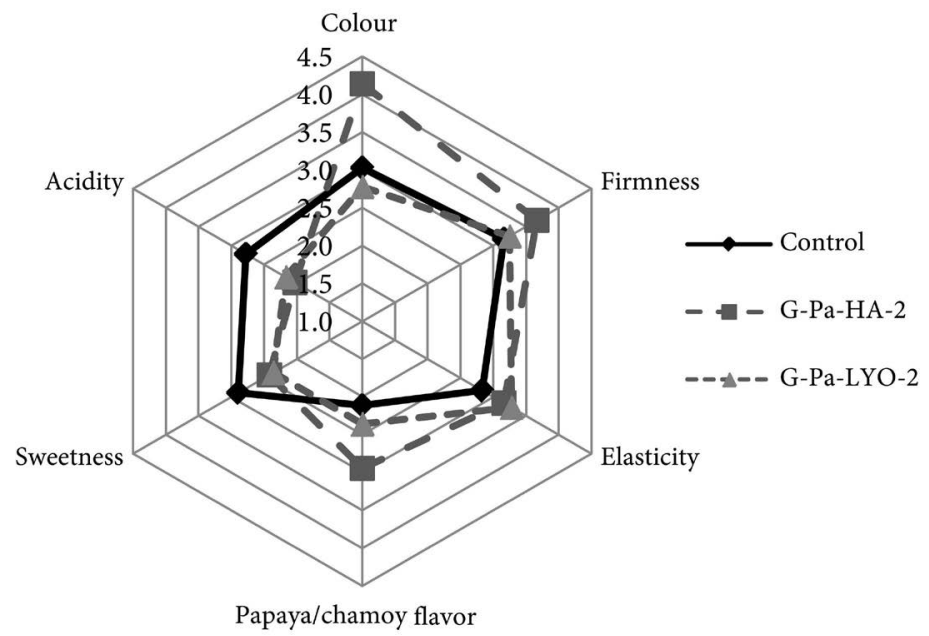

Figure 3. Sensory analysis of papaya candies using a five-point hedonic scale. See Figure 2 for sample identification. 2: particle size $250 \mu \mathrm{m}$ to $<180 \mu \mathrm{m}$.

the control and candies with powders for firmness, sweetness, acidity and elasticity. The panelists preferred those attributes for the control, while the enriched candies were more elastic and firmer, but less sweet and acidic than they like.

\section{Conclusion}

It was possible to produce enriched gummy candies using $5 \mathrm{~g} / 100 \mathrm{~g}$ of pineapple and papaya peel powders. These by-products contributed to enhancing color and instrumental texture regarding powder-free candies, also, to reducing the caloric content and flavoring addition to the products. Samples G-Pi-LYO-3 and G-Pa-LYO-2 presented the best color and texture characteristics; they were more homogeneous and clearer in color and had the greatest firmness and elasticity. These results are consistent with sensory analysis, since the panelists expressed a marked preference for both formulations. Nevertheless, control samples had the highest scores in all their attributes. This result suggests more investigation is required in the future to optimize the formulations. However, the potential exploitation of by-products has been demonstrated.

\section{Acknowledgements}

Thanks are due to Consejo Nacional de Ciencia y Tecnología (CONACyT) for the scholarship to KFRZ (Grant 766686), to Universidad Autónoma de Aguascalientes for the financial support, and the two-local small-scale food units: Las Exquisitas Food \& Snacks, and Jugos y Chocos Tony for your collaboration in this project. The technical support of Rosa Ramirez and Gloria Diaz with instrumental techniques is greatly appreciated.

\section{Conflicts of Interest}

The authors declare no conflicts of interest regarding the publication of this paper. 


\section{References}

[1] Banerjee, J., Singh, R., Vijayaraghavan, R., MacFarlane, D., Patti, A.F. and Arora, A. (2017) Bioactives from Fruit Processing Wastes: Green Approaches to Valuable Chemicals. Food Chemistry, 225, 10-22. https://doi.org/10.1016/j.foodchem.2016.12.093

[2] Selani, M.M., Shirado, G.A.N., Margiotta, G.B., Saldaña, E., Spada, F.P., Piedade, S.M.S., Contreras-Castillo, C.J. and Canniatti-Brazaca, S.G. (2016) Effects of Pineapple Byproduct and Canola Oil as Fat Replacers on Physicochemical and Sensory Qualities of Low-Fat Beef Burger. Meat Science, 112, 69-76. https://doi.org/10.1016/j.meatsci.2015.10.020

[3] Martínez, R., Torres, P., Meneses, M.A., Figueroa, J.G., Pérez-Álvarez, J.A. and Viuda-Martos, M. (2012) Chemical, Technological and in Vitro Antioxidant Properties of Mango, Guava, Pineapple and Passion Fruit Dietary Fibre Concentrate. Food Chemistry, 135, 1520-1526. https://doi.org/10.1016/j.foodchem.2012.05.057

[4] Arias, C.J. and Toledo, J. (2000) Manual de manejo postcosecha de frutas tropicales (papaya, piña, plátano, cítricos) Organización de las Naciones Unidas para la Agricultura y la Alimentación (FAO) [Internet Document].

http://www.fao.org/3/a-ac304s.pdf

[5] Paull, R. and Duarte, O. (2011) Tropical Fruits. In: C.A.B. International, Ed., Crop Production Science in Horticulture, 2nd Edition, CABI, Wallingford, Cambridge, 18-30.

[6] Ketnawa, S., Chaiwut, P. and Rawdkuen, S. (2012) Pineapple Wastes: A Potential Source for Bromelain Extraction. Food and Bioproducts Processing, 90, 385-391. https://doi.org/10.1016/j.fbp.2011.12.006

[7] Larrauri, J.A., Rupérez, P. and Saura-Calixto, F. (1997) Pineapple Shell as a Source of Dietary Fiber with Associated Polyphenols. Journal of Agricultural and Food Chemistry, 45, 4028-4031. https://doi.org/10.1021/jf970450j

[8] Koubala, B.B., Christiaens, S., Kansci, G., Van-Loey, A.M. and Hendrickx, M.E. (2014) Isolation and Structural Characterization of Papaya Peel Pectin. Food Research International, 55, 215-221. https://doi.org/10.1016/j.foodres.2013.11.009

[9] Samson, J. (1986) Tropical Fruits. In: Tropical Agriculture Series, 2nd Edition, Langman Scientific and Technical, New York, 229-233.

[10] Ajila, C.M., Aalami, M., Leelavathi, K. and Prassada Rao, U.J.S. (2010) Mango Peel Powder: A Potential Source of Antioxidant and Dietary Fiber in Macaroni Preparations. Innovative Food Science and Emerging Technologies, 11, 219-224.

https://doi.org/10.1016/j.ifset.2009.10.004

[11] Jiménez-Escrig, A., Rincón, M., Pulido, R. and Saura-Calixto, F. (2001) Guava Fruit (Psidium guajava L.) as a New Source of Antioxidant Dietary Fiber. Journal of Agricultural and Food Chemistry, 49, 5489-5493. https://doi.org/10.1021/jf010147p

[12] Cuq, B., Gaiani, C., Turchiuli, C., Galet, L., Scher, L., Jeantet, R., Mandato, S., Petit, J., Murrieta, I., Barkouti, A., Schuck, P., Rondet, E., Delalone, M., Dumoulin, G., Delaplace, G. and Ruiz, T. (2013) Chapter Two Advances in Food Powder Agglomeration Engineering. Advances in Food and Nutrition Research, 69, 41-103. https://doi.org/10.1016/B978-0-12-410540-9.00002-8

[13] Cuq, B., Rondet, E. and Abecassis, J. (2011) Food Powders Engineering, between Knowhow and Science: Constraints, Stakes and Opportunities. Powder Technology, 208, 244-251. https://doi.org/10.1016/j.powtec.2010.08.012

[14] Selani, M.M., Canniatti-Brazaca, S.G., Santos Dias, T.C., Ratnayake, W.S., Flores, 
R.S. and Bianchini, A. (2014) Characterisation and Potential Application of Pineapple Pomace in an Extruded Product for Fibre Enhancement. Food Chemistry, 163, 23-30. https://doi.org/10.1016/j.foodchem.2014.04.076

[15] Sah, B.N.P., Vasiljevic, T., McKechnie, S. and Donkor, O.N. (2016) Physicochemical, Textural and Rheological Properties of Probiotic Yogurt Fortified with Fibre-Rich Pineapple Peel Powder during Refrigerated Storage. LWT-Food Science and Technology, 65, 978-986. https://doi.org/10.1016/j.lwt.2015.09.027

[16] Chacón, L. (2014) México de los países más dulces del mundo [Internet Document]. http://www.manufactura.mx/industria/2014/08/15/mexico-de-los-paises-mas-dulce s-del-mundo

[17] Jackson, P., Romo, M., Castillo, M. and Castillo-Durán, C. (2004) Las golosinas en la alimentación infantil. Análisis antropológico nutricional. Revista Médica de Chile, 132, 1235-1242. https://doi.org/10.4067/S0034-98872004001000012

[18] Nambiar, A.P., Sanyal, M. and Shrivastav, P.S. (2018) Simultaneous Densitometric Determination of Eight Food Colors and Four Sweeteners in Candies, Jellies, Beverages and Pharmaceuticals by Normal-Phase High Performance Thin-Layer Chromatography Using a Single Elution Protocol. Journal of Chromatography A, 1572, 152-161. https://doi.org/10.1016/j.chroma.2018.08.059

[19] Silva, M.L.S., García, M.B.Q., Lima, J.L.F.C. and Barrado, E. (2007) Voltammetric Determination of Food Colorants Using a Polyallylamine Modified Tubular Electrode in a Multicommutated Flow System. Talanta, 72, 282-288.

https://doi.org/10.1016/j.talanta.2006.10.032

[20] A.O.A.C. (1984) Official Methods of Analysis. 14th Edition, Association of Official Analytical Chemists, Washington DC.

[21] Fukumoto, L.R. and Mazza, G. (2000) Assessing Antioxidant and Prooxidant Activities of Phenolic Compounds. Journal of Agricultural and Food Chemistry, 48, 3597-3604. https://doi.org/10.1021/jf000220w

[22] Re, R., Pellegrinia, N., Proteggentea, A., Pannalaa, A., Yanga, M. and Rice-Evansa, C. (1999) Antioxidant Activity Applying an Improved ABTS Radical Cation Decolorization Assay. Free Radical Biology and Medicine, 26, 1231-1237. https://doi.org/10.1016/S0891-5849(98)00315-3

[23] Singleton, V.L., Orthofer, R. and Lamuela-Raventos, R.M. (1999) Analysis of Total Phenols and Other Oxidation Substrates and Antioxidants by Means of the Folin-Ciocalteau Reagent. Methods in Enzymology, 299, 152-178. https://doi.org/10.1016/S0076-6879(99)99017-1

[24] Ramírez, M. and Orozco, N. (2014) Confitería: De lo artesanal a la tecnología. Editorial Universidad Autónoma de Aguascalientes, México, 106-109.

[25] Gelatin Manufacturers Institute of America (2013) Standard Testing Methods for Edible Gelatin [Internet Document]. http://www.gelatin-gmia.com/uploads/1/1/8/4/118450438/gmia_official_methods_2 019.pdf

[26] ISO 4121 (2003) Sensory Analysis. Guidelines for the Use of Quantitative Response Scales. International Organization for Standardization.

[27] Edwards, W.P. (2000) The Science of Sugar Confectionery. Royal Society of Chemistry, London, 7-8.

[28] Cappa, C., Lavelli, V. and Mariotti, M. (2015) Fruit Candies Enriched with Grape Skin Powders: Physicochemical Properties. LWT_Food Science and Technology, 62, 569-575. https://doi.org/10.1016/j.lwt.2014.07.039 
[29] Huang, Y.L., Tsai, Y. and Chow, C.J. (2014) Water-Insoluble Fiber-Rich Fraction from Pineapple Peel Improves Intestinal Function in Hamsters: Evidence from Cecal and Fecal Indicators. Nutrition Research, 34, 346-354.

https://doi.org/10.1016/j.nutres.2014.03.001 